
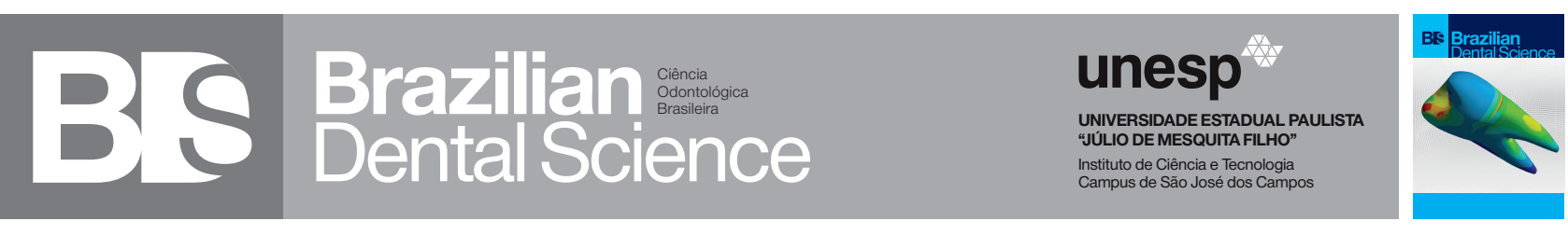

\title{
Are non-carious cervical lesions more frequent in sleep bruxism patients?
}

\author{
Lesões cervicais não cariosas são mais frequentes em pacientes com bruxismo do sono?
}

Jean Soares MIRANDA ${ }^{1}$, Aline Serrado de Pinho BARCELLOS ${ }^{1}$, Alloma de Souza OLIVEIRA², Thaís Cachuté PARADELLA ${ }^{1}$, Estevão Tomomitsu KIMPARA ${ }^{1}$, Maria das Graças Afonso Miranda CHAVES ${ }^{2}$

1 - São Paulo State University (Unesp) - Institute of Science and Technology - São José dos Campos - Department of Dental Materials and Prosthodontics - SP - Brazil.

2 -Department of Restorative Dentistry - School of Dentistry - Universidade Federal de Juiz de Fora - Minas Gerais - Brazil.

\begin{abstract}
Objective: to verify the frequency in non-carious lesions in patients with and without sleep bruxism and to try to list the occurrence of such lesions in patients with this parafunctional habit. Material and Methods: 67 patients ranging from 18 to 70 years of age, which all signed a free and consent form were evaluated. Patients with neurological diseases and/or partially or totally edentulous were excluded from the study. Bruxism diagnosis was performed using a validated questionnaire based on the combination of at least two positive confirmations of bruxism. Diagnosis of non-carious cervical lesions (NCCL) was performed by a single calibrated examiner, using \#5 clinical probe, intraoral mirror and air flow, analyzing all surfaces of the teeth present in the mouth. The lesions were classified as abfraction, abrasion or erosion. Statistical analysis was performed by U MannWhitney test, at 5\% level of significance. Results: sixty patients were diagnosed with bruxism (91.3\%) and only seven patients (8.7\%) did not present this parafuctional habit. Regardless the gender, five patients (10.1\%) presented absence of lesions and 62 patients $(89.9 \%)$ presented some NCCL. 70\% presented abfraction, $41 \%$ abrasion and no patient presented erosion. Statistical analysis showed a p-value of 0.03 , which demonstrated significant statistical difference of NCCL between the groups. Conclusion: a higher frequency of NCCL in patients with bruxism was observed when compared to patients without this parafuction.
\end{abstract}

\section{KEYWORDS}

Abfraction; Bruxism; Non-carious cervical lesions.

\section{RESUMO}

Objetivo: verificar a frequência de lesões não cariosas nos pacientes com e sem bruxismo do sono e tentar relacionar a ocorrência dessas lesões a esse hábito parafuncional. Material e Métodos: foram avaliados 67 pacientes com idade entre 18 e 70 anos, os quais assinaram um termo de consentimento livre e esclarecido. Foram excluídos da pesquisa pacientes com doenças neurológicas e/ou endêntulos parciais ou totais. O diagnóstico de bruxismo foi realizado através de um questionário validado que se baseiam na combinação de pelo menos duas constatações positivas de bruxismo. O diagnóstico das lesões cervicais não cariosas (LCNC) foi realizado por um único examinador calibrado, e observadas mediante utilização de sonda clínica $n^{\circ} 5$, espelho clínico intraoral e jato de ar, analisando todas as faces de todos dos dentes presentes em boca. Essas foram classificadas em abfração, abrasão ou erosão. A análise estatística foi realizada pelo teste U de Mann-Whitney para tratamento estatístico com nível de significância de 5\%. Resultados: sessenta pacientes foram diagnosticados com bruxismo $(91,3 \%)$ e apenas sete pacientes $(8,7 \%)$ não possuíam esse hábito parafuncional. Independente do gênero, cinco pacientes $(10,1 \%)$ possuíam ausência e sessenta e dois pacientes (89,9\%) possuíam presença de alguma LCNC. 70\% possuíam abfração, $41 \%$ abrasão e nenhum paciente apresentou erosão. O teste estatístico obteve um p-valor igual a 0,03; demostrando uma diferença estatisticamente significativa da presença de LCNC entre os grupos. Conclusão: nota-se que houve uma maior frequência de LCNC em pacientes com bruxismo em comparação ao grupo que não apresentou essa parafunção.

\section{PALAVRAS-CHAVE}

Abgração; Bruxismo; Lesão cervical não cariosa. 


\section{INTRODUCTION}

$\mathrm{N}$ on-carious cervical lesions (NCCL) are clinical routinely found pathological processes, characterized by the loss of dental structure in the cement-enamel junction, regardless of the bacterial process [1]. Studies have shown that these lesions are prevalent in up to $85 \%$ of the population [2,3], and such lesions may be characterized as either erosion, abrasion or abfraction [2,4,5].

Erosion is caused by a chemical process of acid action [6,7]. However, abrasion is associated to mechanical stress, such as traumatic brushing or the usage of abrasive tooth pastes [4]. Thus, abfraction is the pathological loss of mineralized tooth structure due to biomechanical forces, which cause dental flexion and, consequently, enamel and dentin fatigue, in a distant location regarding occlusal loading [8,9].

Studies have shown that such lesions are multifactorial $[2,7,10,11]$. It has been suggested that, although the initiative factor has not yet been established, stress is responsible for abfraction lesions, making the system more susceptible to the formation of other secondary lesions $[5,8,11]$. Such stress is allegedly related to parafunctional habits such as centric and eccentric bruxism $[5,7,12]$.

Bruxism, term used to describe the static or dynamic contact of teeth occlusion that is not executed during regular function and/or deglutition, is considered the most harmful physiopathological disturb in all the parafunctional activities of the stomatognathic system [14]. Eccentric bruxism (sleep bruxism), characterized by the habit of grinding teeth during sleep, occurs in $12.8 \%$ of adults and $35.3 \%$ of children [15]. Due to this impacting prevalence of bruxism in the population and data that this activity may be related to NCCL $[7,12]$, the purpose of this study was to verify the frequency of NCCL in bruxism patients evaluated in the Service of Diagnosis and Guidance of
Temporomandibular Joint Disorders (TMJ Service) from the Dentistry College, Juiz de Fora University, Minas Gerais (UFJF - MG), Brazil, to establish the relationship between those two events (bruxism and NCCL). The null-hypothesis was that there were no differences between the prevalence of NCCL between bruxism groups and groups without bruxism.

\section{METHODOLOGY}

For this transversal study, 67 patients, aging from 18 to 70 , being 48 female and 19 male, all in treatment at the TMJ Service from the Dentistry College, Juiz de Fora University, Minas Gerais (UFJF - MG), Brazil, were chosen. This number of patients was defined by the formula for calculating the population expectation for disease occurrence, with 95\% accuracy and an admissible error of 5\% [15]. All patients signed a informative consent term and the study was conducted following the patterns required by the Helsinki declaration and submitted to the Human Research Ethics Committee from the UFJF, (\#310.561/2013).

This age range was chosen since it matches literature, once sleep bruxism although diminishes with age, can be found in different stages of life [16]. In addition, NCCL seem to be found in all ages [3,9]. The exclusion criteria adopted in the study was the presence of neurological diseases, once those can initiate secondary bruxism associated to a medical cause, not being the purpose of the present study. Totally or partially edentulous patients were also excluded from the study, being the third molar absence the only acceptable absence.

Primarily, patients were evaluated regarding sleep bruxism, through Lavigne, Rompré and Montplaisir [17] validated criteria, and Lavigne and Manzini [18], which are based on the combination of at least two of the following clinical confirmations: 1) history of shear noise and/or grinding of the teeth, confirmed by a roommate or family member; 2) wear facets on the teeth's surface, incompatible 
with age and function; 3 ) headache on the region of the temporal muscle; 4) rigid mandibular muscle or fatigued muscles during the night or on waking; 5) mandibular locking or difficulty in opening of the mouth by morning; 6) teeth xamshypersensitivity; 7) masseter hypertrophy.

To observe and diagnose NCCL, a single calibrated examiner participated in the study by using number 5 clinical probe, intraoral mirror and air flow, observing all the faces of the teeth present in the mouth. Lesions were characterized as erosion, abrasion or abfraction, according to the characteristics described by Neville [19] and through part of the form corresponding to NCCL described by Costa [20].

Although selection bias may be a problem in epidemiological studies, the recruitment unit of the present study population is a reference center for the city and micro-region, which assist a population with different socioeconomic status, education, age, among other variables confounding. But the bias for diagnostic problems were solved with training a single examiner for applying the exams.

Data was tabulated using Excel 2013 and submitted to statistical tests using software $\mathrm{R}$ version 3.3.2. ( $R$ Windows FAQ, EUA), being calculated the absolute, relative and mean frequency, for bivariate comparison using MannWhitney U test at 5\% level of significance.

\section{RESULTS}

From the total sample, $29 \%$ of the patients were male and $71 \%$ were female, being 33 the mean age, with higher representative of patients aging from 20 to 25 (61.9\%). Regarding the presence or absence of parafunctional bruxism, 60 patients (91.3\%) presented this parafunctional habit and only seven patients (8.7\%) did not.

To verify the difference in the frequency of the presentation of NCCL, the number of the teeth presenting any type of lesion was added to the number of the patients. Regardless the gender, seven patients (10.1\%) presented absence of lesions and sixty two patients (89.9\%) presented some type of NCCL.

The frequency of NCCL are presented in table 1.

Table 1 - Frequency of the different NACLs in the sample. Several types and numbers of lesions were found in the same patient

\begin{tabular}{|ccc|}
\hline Lesion & $\begin{array}{c}\text { Number of lesions in } \\
\text { the sample }\end{array}$ & $\begin{array}{c}\text { Percentage of } \\
\text { lesions in the sample } \\
\text { (\%) }\end{array}$ \\
\hline Abfraction & 47 & 70 \\
\hline Abrasion & 27 & 41 \\
\hline Erosion & 0 & 0 \\
\hline
\end{tabular}

The incidence of NCCL in the selected sample is shown in figure 1 . It is noticed that the group with bruxism presented a similar distribution when compared to the total of the population, around eleven lesions, being closest to the normality when compared to the group without bruxism, which presented the great majority of the patients showing between zero to ten lesions.

Given that one of the groups deviate significantly from a normal distribution, a non-parametric hypothesis test should be used. Therefore, a Mann-Whitney U test has been conducted as a one-tailed test to detect if there is a negative location shift with a 95\% significance level. The resulting statistics for the sample showed $U=124$ with a p-value of 0.03 , indicating that the test is statistically significant.

\section{DISCUSSION}

For some time, the correlation between occlusal pathology and NCCL has been the purpose of epidemiological studies, which have evaluated demographic data, form of lesions, parafunctional habits, occlusal factors, dieting and hygiene habits, through clinical examination, questionnaires and function evaluations $[5,21]$. 

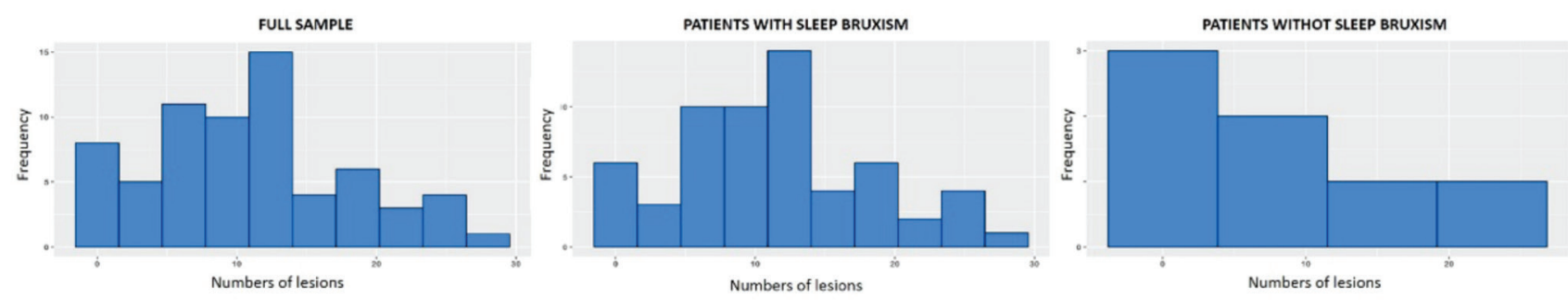

Figure 1 - Histograms of incidence of NCCL in the general evaluated populations (a), in the groups with bruxism (B) and in groups without this condition (C). It is possible to notice the difference in the quantity of NCCL by patients between both groups. The frequency in the graphics refers to the number of lesion in each patient.

In the present study, which had the intention of verifying the presence and frequency of lesions in patients with and without bruxism, it was noticed that both were more frequent and numerous in patients with the parafunction. The null-hypothesis was rejected in favor of the alternate hypothesis.

The number of the lesions found in bruxism patients was statistically higher when compared to the control group, which corroborates some findings in the literature $[1,12,22]$, which although do not present grinding of the teeth as cause of NCCL, they considered grinding an exacerbating factor [9], mainly for lesions such as abfraction [1].

Some studies stated that many lesions could not be described just as abrasion or erosion caused by toothbrushes $[7,11]$, therefore some authors tried to associate those lesions with poor dental occlusion $[3,4,9,10]$. However, Gibbs et al. [23] discovered that occlusion forces during deglutition and chewing are only 40\% of the maximum chewing force. Suit et al. [24] stated that the occlusal contact during chewing occurs for only 194 milliseconds and for 683 milliseconds during deglutition. Considering that the duration and strength of forces during bruxism are higher than those during functional activity, it is more likely that a parafunction would result in such process [11].

Parafunctional habits, such as night or day bruxism may produce elevated stress loads on the stomatognathic system $[25,26]$. When tooth flexion occurs, shear tensions concentrate on the cervical region, through axial and lateral loading, which may cause fatigue and rupture of the connections of the hydroxyapathite crystals, leading to the formation of pits and fissures, and eventually the weakening and loss of subjacent enamel and dentin $[2,7,10,11]$. When associating this process with acidic dieting and abrasion, progression of lesions may occur. The combination of ethiological factors and the longer permanence of teeth in the mouth can lead to more severe NCCL [2].

Thus, to perform a correct bruxism diagnosis, one must pay attention to scientific research. This diagnosis can be underestimated if only wear facets were the single diagnostic measurements [11]. Previous researches have ignored such fact, so caution must be taken when evaluating the results [11]. In addition, bruxism involves not only tightening but also grinding of the teeth [14]. Tightening is the characteristic of day bruxism and may not result in wear facts, although could lead to tooth flexion. For the bruxism diagnosis in the present study, the Lavine, Rompré and Montplaisir [17] validated questionnaire was chosen, which is based on at least two clinical confirmations, as described previously.

Regarding the number of lesions per patient, it was noticed a high number of 11 lesions per patient. This result is superior than the one found in the literature [4]. Oliveira, Catão and Carneiro [4] found a mean number of four lesions per individual, however the sample was not composed by mostly of patients with 
sleep bruxism, which is the case in the present study, justifying the difference in the number of NCCL.

Also different from other studies [2,10], the population evaluated in the present study was composed mainly by female gender. Once again, the sample can be pointed out as responsible for the difference in the results, since it was composed by patients with Temporomandibular Disorders attending a service which is frequented mostly by women, who frequently search more for professional help than men [27]. Thus, it is not possible to generalize the results to other areas, not even other geographic areas, once it only reflects the reality of the patients of the TMJ Service from the Dentistry College Juiz de Fora University, Minas Gerais.

Meanwhile, in the sample from the present study, as well as in Oliveira, Catão and Carneiro [4], the population was composed mainly by young adult patients. However, the number of NCCL seems to enhance with age $[1,3,9]$, with suggests the fatigue component in its formation [1], and also considering the natural consequence of risk factors exposure for a long period of time, characterizes NCCL as a chronic condition [9].

However, with this study, it can only be stated that the number of NCCL was higher in bruxism patients. However, it is not possible to define that this parafunction is the cause of those lesions, since in the present experimental design, data was collected after the pathology was present. To establish this type of cause-effect, all variables must be considered simultaneously, since it is quite difficult to isolate the ethiological agents in a single moment of evaluation [2,9]. In addition, the number of patients without bruxism was small, when compared to the bruxism patients, which could generate a possible statistical bias, suggesting that further longitudinal researches should be performed with a bigger population, so more conclusive results can be obtained.

\section{CONCLUSION}

Although a cause-effect relationship could not be established, it was noticed that NCCL appeared more frequently in bruxism patient when compared to the group that did not present this parafunction.

\section{REFERENCES}

1. Faye B, Sarr M, Benoist FL, Ndiaye D, Bane K, Lo CM, Toure B. Prevalence and Etiologic Factors of Non-Carious Cervical Lesions among Prison's Population in Dakar. J Dent Oral Care Med. 2015 Nov;1(3):1-6.

2. Oliveira ACS, Damascena NP, Souza CS. Análise clínica de pacientes portadores de lesões cervicais não cariosas e sua relação com hábitos. Rev Sul-Bras 0dontol. 2010 Jun;7(2):182-92.

3. Smith WA, Marchan S, Rafeek RN. The prevalence and severity of non-carious cervical lesions in a group of patients attending a university hospital in Trinidad. J Oral Rehabil. 2008 Feb;35(2):12834.

4. Oliveira RL, Catão MHCV, Carneiro VSM. Prevalência de lesões cervicais não cariosas em acadêmicos de Odontologia da Universidade Estadual da Paraíba. Braz Dent Sci. 2011 JulDec;14(1):54-61.

5. Sousa AMT, Prado RA, Castro Filho AA. Fatores de risco oclusais e sua influência na etiologia das lesões cervicais não-cariosas. Rev Dent Online. 2012;11:23.

6. Hobkirk JA. Tooth surface loss: causes and effects. Int J Prosthodont. 2007 Jul-Aug;20(4):340-1.

7. Bartlett DW, Shah P. A critical review of non-carious cervical (wear) lesions and the role of abfraction, erosion, and abrasion. J Dent Res. 2006 Apr;85(4):306-12.

8. Ravi RK, Krishnaalla R, Mohammed S, KSV R. Non-carious lesions due to tooth surface loss: a review. Dent Era - A Journal of Dentistry. 2013 Sep;3(3):35-40.

9. Senna P, Del Bel Cury A, Rösing C. Non-carious cervical lesions and occlusion: a systematic review of clinical studies. J Oral Rehabil. 2012 Jun;39(6):450-62.

10. Lai ZY, Zhi QH, Zhou Y, Lin HC. Prevalence of non-carious cervical lesions and associated risk indicators in middle-aged and elderly populations in Southern China. Chin J Dent Res. 2015 Jan;18(1):4150 .

11. Michael JA, Townsend GC, Greenwood LF, Kaidonis JA. Abfraction: separating fact from fiction. Aust Dent J. 2009 Mar;54(1):2-8.

12. Veitz-Keenan A, Barna JA, Strober B, Matthews AG, Collie D, Vena $D$, et al. Treatments for hypersensitive noncarious cervical lesions: a Practitioners Engaged in Applied Research and Learning (PEARL) Network randomized clinical effectiveness study. J Am Dent Assoc. 2013 May;144(5):495-506.

13. Dias IM, Mello LMR, Maia ID, Reis LO, Leite ICG, Leite FPP. Avaliação dos fatores de risco do bruxismo do sono. Arq Odontol Belo Horizonte. 2014 Jul-Set;50(3):113-20.

14. Dias IM, Maia ID, Mello LMR, Leite ICG, Leite FPP. Evaluation of 
correlation among sleep bruxism and depression levels, chronic pain and nonspecific physical symptoms according to axis II of the Research Diagnostic Criteria / Temporomandibular disorders. RSB0. 2014 0ct-Dec;11(4):352-9.

15. Jekel JF, Katz DL, Elmore JG. Epidemiologia, bioestatística e medicina preventiva. Porto Alegre: Artmed; 2005.

16. Manfredini D, Restrepo C, Diaz-Serrano K, Winocur E, Lobbezoo F. Prevalence of sleep bruxism in children: a systematic review of the literature. J Oral Rehabil. 2013 May;40(8):631-42.

17. Lavigne GJ, Rompré PH, Montplaisir JY. Sleep bruxism: validity of clinical research diagnostic criteria in a controlled polysomnographic study. J Dent Res. 1996 Jan;75:546-52.

18. Lavigne GJ, Manzini C. Bruxism. In: Kryger MH, Roth T, Dement WC Principles and practice of sleep medicine. Philadelphia:Elsevier. 6 Ed. 2017.

19. Neville BW. Patologia Oral e Maxilofacial. Rio de Janeiro:Elsevier. 4 Ed. 2016.

20. Costa, LC. Prevalência de lesões dentárias não cariosas e sua relação com processos erosivos [tese]. Bauru:Universidade de São Paulo, Faculdade de Odontologia de Bauru; 2007.
21. Aw TC, Lepe X, Johnson GH, Mancl L. Characteristics of noncarious cervical lesions: a clinical investigation. J Am Dent Assoc. 2002 Jun;133(6):725-33.

22. Ommerborn MA, Schneider C, Giraki M, Schafer R, Singh P, Franz $M$, et al. In vivo evaluation of noncarious cervical lesions in sleep bruxism subjects. J Prosthet Dent. 2007;98(2):150-8.

23. Gibbs CH, Mahan PE, Lundeen HC, Brehnan K, Walsh EK, Holbrook WB. Occlusal forces during chewing and swallowing as measured by sound transmission. J Prosthet Dent. 1981;46:443-9.

24. Suit SR, Gibbs CH, Benz ST. Study of gliding contacts during mastication. J Periodontol. 1976 Jun;47:331-4.

25. Rees JS. The biomechanics of abfraction. Proc Inst Mech Eng H. 2006 Jan;220(1):69-80.

26. Borcic J, Anic I, Smojver I, Catic A, Miletic I, Ribaric SP. 3D finite element model and cervical lesion formation in normal occlusion and in malocclusion. J Oral Rehabil. 2005;32(7):504-10.

27. Lima C0, Caetano PL, Miranda JS, Malta NV, Leite ICG, Leite FPP. Evaluation of the life quality in patients with Temporomandibular Disorders. Braz Dent Sci. 2015 Jul-Sep;18(3):77-83.

\section{Jean Soares Miranda \\ (Corresponding address)}

Institute of Science and Technology, Paulista State University (UNESP), Department of Dental Materials and Prosthodontics.

Av. Engenheiro Francisco José Longo, 777, Jardim São Dimas, São José dos Campos, São Paulo.

CEP: 12245000

Phone: +55 32988239151

Date submitted: 2017 Jun 25

e-mail: jeansoares@msn.com 